\title{
| Parvovirus B19 incidence, specific anti- body response, and delayed hematopoietic recovery after allogeneic hematopoietic stem cell transplantation
}

\begin{abstract}
Irina V. Khamitova, Irina N. Lavrentyeva, Maria Yu. Averyanova, Alexey B. Chukhlovin, Ludmila S. Zubarovskaya, Boris V. Afanasyev

L. Pasteur Research Institute of Epidemiology and Microbiology, St.Petersburg, Russia; R. Gorbacheva Memorial Research Institute of Children Oncology, Hematology and Transplantation, The First St. Petersburg State Medical I. Pavlov University, St. Petersburg, Russia
\end{abstract}

Dr. Irina V. Khamitova, Head, Central Laboratory for Clinical Diagnostics, L. Pasteur Research Institute of Epidemiology and Microbiology, Mira St 14, 197101, St. Petersburg, Russia

\section{Summary}

Parvovirus B19 (PVB19) is a well known DNA virus which seems to be associated, e.g., with erythropoiesis disturbances. Being a latent virus, the PVB19 may become active in immunocompromised patients. However, clinical significance of PVB19 after hematopoietic stem cell transplantation (HSCT) is yet not clear. Therefore, the aim of our study was compare the PVB19 DNA levels prior to allogeneic HSCT, and at 1-2 months post-transplant, as well as search for correlations with specific antibody levels and possible effects upon hematopoietic recovery within 60 days after HSCT. Our study included 54 pediatric and adolescent patients of 0.6 to 19 years old with blood malignancies or inherited disorders who underwent allogeneic HSCT. Fifty-one patient of this group were observed for at least 60 days after HSCT. 33\% of the patients were in first remission after previous treatment. Non-myeloablative conditioning treatment was used in $94 \%$ of cases. Antilymphocyte immune globulin and/or cyclophosphamide were applied as immunosuppressive therapy. Determination of the PVB19 DNA as well as herpesviruses (CMV, EBV, HSV) and polyomaviruses (BK, JC) was performed before conditioning therapy which preceded allo-HSCT, as well as on day $+30(\mathrm{D}+30)$ and day+60 $(\mathrm{D}+60)$ post-transplant. Quantitative determination of the PV B19 DNA was performed by gene-specific real-time PCR using commercial kits. IgG and IgM antibodies to PVB19 were determined quantitatively by means of ELISA method.
Phone: +7 (812) 2323155

E-mail: irina.khamitova@gmail.com

Results of the study were as follows: PVB19 DNA at low levels was found in blood plasma samples of 31.5\% HSCT patients. However, $68 \%$ of the patients exhibited detectable levels of IgG-anti-PVB19 antibodies (>10 IU/ $\mathrm{ml}$ ), thus reflecting high prevalence of adaptive immune response. Generally, prevalence and mean levels of PV B19 DNA as well as concentrations of anti-PV B19 antibodies did not show any significant changes at 30 or 60 days after HSCT.

Meanwhile, a significant positive correlation was revealed between the overall PVB19 viral load and serum levels of IgG antiviral antibodies $(\mathrm{r}=0.351 ; \mathrm{p}<0.0001)$. Moreover, positivity for PVB19 DNA by the day +30 after allo-HSCT was in all cases (14/14), associated with febrile neutropenia in the patients, thus suggesting their potential role in posttransplant infections.

Specifically, important correlations were observed between initial parvovirus DNA detection, and delayed reconstitution of erythrocytes and platelets in peripheral blood (respectively, $r=-0,281 ; p=0.02 ; r=-0,303, p=0.01$ ). Moreover, a marked correlation was shown by the day +60 between decreased neutrophils and platelet counts, and increased anti-PVD19 antibody levels. This finding may suggest an association between parvovirus activation and slower hematopoiesis recovery after allogeneic HSCT.

\section{Keywords}

Hematopoietic stem cell transplantation, parvovirus B19, activation, antiviral antibodies, myelosuppression, febrile neutropenia. 


\section{Introduction}

Parvovirus B19 (PVB19) is a well known small DNA virus from Erythrovirus genus which is in scope of pediatricians for decades being associated with erythropoiesis disturbances, arthropathies, myocarditis and other disabling clinical conditions [1]. PVB19 shows an affinity for the group P antigen of red blood cells, with lesser amounts in blood plasma [2]. The major hematotoxic effect of the virus is believed to occur at the pronormoblast stage, thus causing arrest of erythroid differentiation. PVB19 was occasionally found in aplastic anemias and pure red cell aplasia [3]. In this respect, most studies concerned resistant anemia cases in the patients subjected to renal transplantation where the PVB19 was not a rare finding [4].

Over past years, many cases of severe myocarditis and hepatitis were shown to be associated with parvovirus infection, as based on positive PVB19 antigen or DNA findings in affected tissues. Meanwhile, a latent persistence of PVB19 was quite common in skin, synovial tissues, myocardium and bone marrow [5]. The viral DNA was detectable in peripheral blood from $5 \%$ of healthy donors [6]. The authors suggest only a small risk for the donor-recipient viral transmission upon hematopoietic stem cell transplantation (HSCT).

Following allogeneic HSCT, a regular activation of herpesviruses and other latent pathogens is observed, due to acute myelosuppression and cellular immune deficiency [7]. Clinical significance of the PVB19 in immunocompromised patients is not yet properly evaluated. E.g., a prolonged study of the PVB19 viral load has been performed in 53 patients after allo-HSCT using quantitative PCR [8]. Specific viral DNA was detectable in blood serum from $30 \%$ of the HSCT recipients, either before, or after HSCT, at maximal viral load observed 2 months post-transplant. However, the patients with detectable PVB19 did not show specific clinical symptoms that could be ascribed to parvovirus infection.

Hence, the aim of our work was to compare the PVB19 DNA levels prior to allogeneic HSCT, and at 1-2 months post-transplant, as well as search for correlations with specific antibody levels, and rates of hematopoietic recovery within 60 days after allo-HSCT. Our preliminary data point to a prognostic significance of parvovirus DNA detection and increased antibody levels as possible predictors for delayed engraftment and febrile neutropenia.

\section{Table 1. Clinical and demographic characteristics of the patients at allo-HSCT}

\begin{tabular}{|l|l|}
\hline Parameter & Values, years or per cent \\
\hline Age, years (median value) & 7.2 years (0.6 mo - 19 years) \\
\hline Gender: & \multicolumn{2}{|l|}{} \\
\hline Male & $50 \%(27)$ \\
\hline Female & $50 \%(27)$ \\
\hline Primary diagnosis: & \multicolumn{2}{|l|}{} \\
\hline Acute leukemia & $55.5 \%(30)$ \\
\hline AML & $30 \%(16)$ \\
\hline ALL & $26 \%(14)$ \\
\hline Chronic myeloid leukemia & $1.8 \%(1)$ \\
\hline Malignant lymphomas & $3,6 \%(2)$ \\
\hline Juvenile myelomonocytic leukemia & $7,5 \%(4)$ \\
\hline Neuroblastoma & $3,6 \%(2)$ \\
\hline Severe aplastic anemia & $9 \%(5)$ \\
\hline Fanconi anemia & $1,8 \%(1)$ \\
\hline Beta-thalassemia & $1,8 \%(1)$ \\
\hline Wiscott-Aldrich syndrome & $1,8 \%(1)$ \\
\hline Osteopetrosis & $1,8 \%(1)$ \\
\hline Type 1 mucopolysaccharidosis & $11 \%(6)$ \\
\hline Stage at the time of allo-HSCT & $33 \%(18)$ \\
\hline Remission 1 & $18.5 \%(10)$ \\
\hline Remission 2 or more & $20.5 \%(11)$ \\
\hline Absence of remission & $28 \%(15)$ \\
\hline Nonmalignant disease & \\
\hline
\end{tabular}




\section{Patients and Methods}

A total of 54 pediatric and adolescent patients were involved into the study at the median age of 7.2 (0.6 to 19 years old), who had a malignant disease of hematopoiesis or inherited disorders as initial diagnosis who underwent allogeneic hematopoietic stem cell transplantation (allo-HSCT). Fifty-one patient of this group were observed for at least 2 months (60 days) after HSCT. Selection of the patients for allo-HSCT, choice of conditioning regimens, prophylaxis of acute graftversus-host disease was performed according to current EBMT recommendations. Most part of this group was represented by the patients with acute myeloblastic leukemia (AML, $\mathrm{n}=16 ; 30 \%$ ), acute lymphoblastic leukemia (ALL, $\mathrm{n}=14 ; 26 \%)$; severe anemias (SAA) of different origin (13\%; $\mathrm{n}=7$ ). $33 \%$ of the patients were in first remission after previous treatment. Socio-demographic features their distribution for diagnosis and stage of the disease, main parameters of allo-HSCT, are shown in Tables 1 and 2.

Bone marrow was used as a source of hematopoietic stem cells in $83 \%$ of cases ( 45 of 54 patients), infusion of peripheral stem cells was applied in the rest of cases. Allo-HSCT from unrelated donors was performed in $45 \%$ of cases $(24$ of 54); grafting from matched related donors or haploidentical transplant was carried out in, resp., 20\% (11/54) and $35 \%(19 / 54)$ patients. Reduced-intensity conditioning was used in nearly all cases (51 of 54 patients). Development of acute GvHD within early period after allo-HSCT was observed in 25 patients, of them, 9 exhibited grade 3-4 GvHD.

Regular examination of the patients before and after HSCT was carried out according to a standard local clinical protocol. He study was approved by the Local Institutional Board at the St.Petersburg State I. Pavlov Medical University. The laboratory studies included routine blood counts and serum biochemistry, urinalysis etc. Quantitative determination of the PVB19 DNA as well as herpesviruses (CMV, EBV, HSV) and polyomaviruses (BK, JC) in blood plasma was performed before conditioning therapy which preceded allo-HSCT, as well as on day $+30(\mathrm{D}+30)$ and day+60 $(\mathrm{D}+60)$ post-transplant. DNA extraction from the samples and quantitative evaluation of PVB19 DNA in the samples were performed by means of PCR with specific fluorescent probes using "Ampliprime" amplification kits» and "Amplisens ${ }^{\circledast}$ Parvovirus B19-FL» (Moscow, Russia). Moreover, quantitative determination of IgM and IgG antibodies to PV B19 was performed by means of ELISA at $0,+30$ and +60 days post-transplant

Table 2. Main characteristics of allogeneic HSCT in the group under study

\begin{tabular}{|c|c|}
\hline Parameters & Value, \% (abs.) \\
\hline \multicolumn{2}{|l|}{ Stem cell source } \\
\hline Bone marrow & $83 \%(45)$ \\
\hline Peripheral stem cell cells & $17 \%(9)$ \\
\hline \multicolumn{2}{|l|}{ Donor type, HLA and ABO-compatibility } \\
\hline Nonrelated, compatible & $37 \%(20)$ \\
\hline Nonrelated, partially matched & $8 \%(4)$ \\
\hline Related matched & $20 \%(11)$ \\
\hline Related, partially matched & $35 \%(19)$ \\
\hline Full match for $A B 0$ system & $50 \%(27)$ \\
\hline Major mismatch for $A B 0$ system & $22 \%(12)$ \\
\hline Minor mismatch for $\mathrm{AB} 0$ system & $28 \%(15)$ \\
\hline \multicolumn{2}{|l|}{ Conditioning regimen } \\
\hline Non-myeloablative (RIC) & $94 \%(51)$ \\
\hline Myeloablative (MAC) & $6 \%(3)$ \\
\hline Graft cellularity, CD34+ cells 106/kg (median value) & $5.4(1.1-15.6)$ \\
\hline \multicolumn{2}{|l|}{ Immunosuppressive therapy used in conditioning regimens } \\
\hline Fludarabin & $100 \%(54)$ \\
\hline Antilymphocyte (antithymocyte) immunoglobulin (ALG/ATG) & $26 \%(14)$ \\
\hline Cyclophosphamide usage in GvHD prophylaxis & $72 \%(39)$ \\
\hline Usage of granulocyte colony-stimulating factor (G-CSF) & $35 \%(19)$ \\
\hline
\end{tabular}


using «Anti-Parvovirus B19 ELISA IgM» and «Anti-Parvovirus B19 ELISA IgG» kits (EUROIMMUN, Germany). The diagnostic kits were used according to instruction. Statistical evaluation of the data was performed with a Winstat software package.

\section{Results}

\section{Transplant-related changes of PVB19 DNA levels} and anti-PVB19 antibodies

The pre-transplant contents of PVB19 DNA and IgG antibodies to the virus showed a broad-range scatter (Table 3). PVB19 was found in about $30 \%$ of this group. Meanwhile, $68 \%$ of the patients exhibited increased levels of IgG-antiPVB19 antibodies (>10 IU/ml), thus reflecting high prevalence of adaptive immune response. Mean pre-transplant contents of PVB19 DNA did not correlate either with age of the patients, or with clinical disease status, physical state, or activation of other latent viruses.

The detectability and average levels of PVB19 DNA as well as concentrations of anti-PVB19 antibodies did not show any significant changes at 30 or 60 days after HSCT, as seen from Table 1. However, actual scatter of these data proved to be rather sufficient, thus suggesting some correlations between these laboratory indexes and clinical signs in the individual patients. In particular, positive (non-zero) viral loads have been registered in $28 \%$ before allo-HSCT, $29 \%$ and $30.4 \%$ on day+30 and day+60 after allo-HSCT, i.e., ca $70 \%$ of the patients showed negative results for PVB19 over the early period after allo-HSCT.

\section{Association between the PVB19 presence and} specific antibody response after allogeneic HSCT Detection of PVB19 DNA, both before and after allo-HSCT was not accompanied by IgM antibody detection at any observation point, thus suggesting absence of acute infectious process caused by parvovirus infection.

Meanwhile, a significant positive correlation was revealed between the overall PVB19 viral load and serum levels of IgG antiviral antibodies $\left(\mathrm{r}=0.351 ; \mathrm{p}=8 \times 10^{-6}, 153\right.$ assays in 54 clinical cases). In particular, a significant correlation was shown between initial viral load and anti-PVB19 levels at all three terms of the study (Table 3) being, however, maximal at the day+60 after allo-HSCT.

Table 3. Mean and median values for serum IgG PVB19 antibodies and specific viral DNA before and at different terms after allo-HSCT

\begin{tabular}{|c|c|c|c|}
\hline Parameters studied & \multicolumn{3}{|c|}{ IgG-antibodies to PVB19 (ME) } \\
\hline Study terms & Pre-HSCT & Day +30 & Day +60 \\
\hline Number of cases & 54 & 51 & 49 \\
\hline Mean values & 21.7 & 24.8 & 22.8 \\
\hline SE & 3.7 & 3.4 & 3.6 \\
\hline SD & 26.9 & 24.1 & 25.4 \\
\hline Median & 10.7 & 18.8 & 12,5 \\
\hline Minimum & 0.0 & 1.6 & 1.5 \\
\hline \multirow[t]{2}{*}{ Maximum } & 100.0 & 96.3 & 110.0 \\
\hline & \multicolumn{3}{|c|}{ Parvovirus B19 DNA, copy number per $\mathrm{mL}$} \\
\hline Study terms & Pre-transplant & Day +30 & Day +60 \\
\hline Number of cases & 54 & 51 & 49 \\
\hline Mean values & 27.2 & 32.9 & 25.7 \\
\hline SE & 6.7 & 9.7 & 6.8 \\
\hline SD & 49.5 & 68.8 & 47.3 \\
\hline Median & 0 & 0 & 0 \\
\hline Minimum & 0 & 0 & 0 \\
\hline \multirow[t]{2}{*}{ Maximum } & 178.3 & 280.9 & 222.2 \\
\hline & \multicolumn{3}{|c|}{$\begin{array}{l}\text { Correlations between the pre-transplant viral load and IgG anti-PVB19-antibodies at } \\
\text { different terms after HSCT }\end{array}$} \\
\hline Study terms & Pre-HSCT (Day 0) & Day +30 & Day +60 \\
\hline $\mathrm{R}$ quotient & 0.367 & 0.274 & 0.464 \\
\hline P significance level & 0.003 & 0.02 & 0.0004 \\
\hline
\end{tabular}


As seen from Fig. 1, a significant correlation exists between pre-transplant PVB19 load and expressed antibody response detected 60 days after allo-HSCT, i.e., the non-zero viral loads were associated with higher contents of specific antibodies, thus suggesting an association between the PVB19 persistence and production of virus-specific antibodies (Fig. 1).

A half-life time for endogenous IgG antibodies in humans is about 1 to 4 weeks [10]. These findings suggest an opportunity of specific antibody production at early terms after intensive cytostatic treatment, due to potential activity of surviving memory cells, e.g., plasmocytes which are able to function for months and even years after their maturation.

\section{Parvovirus B19 activation and hematopoiesis recovery}

In our clinical series, altered engraftment was, generally, more common at increased IgG PVB19 antibody levels when determined 60 days after HSCT $(r=0.315 ; \mathrm{p}=0.034 ; \mathrm{n}=46)$.

Specifically, significant correlations were shown between initial parvovirus DNA detection, and delayed reconstitution of erythrocytes and platelets in peripheral blood (respectively, $\mathrm{r}=-0,281 ; \mathrm{p}=0.02 ; \mathrm{r}=-0,303, \mathrm{p}=0.01$ ). Moreover, a marked correlation was shown by the day +60 between decreased neutrophils and platelet counts, and increased anti-PVD19 antibody levels (Fig. 2-4). This association may suggest a relation between continued parvovirus persistence and slower hematopoiesis recovery at 30 to 60 days post-transplant.

In general, altered engraftment was also registered in cases with higher IgG antibodies against parvovirus 60 days after HSCT $(r=0.315 ; \mathrm{p}=0.034 ; \mathrm{n}=46)$.

\section{Parvovirus detection and febrile neutropenia}

Positivity for PVB19 DNA by the day +30 after allo-HSCT was, in all cases (14/14), associated with febrile neutropenia (FN), as compared to $68 \%$ in patients with nondetectable PVB19 (23/34; $\mathrm{p}=0.015$, see Table 4). Hence, active parvovirus infection could be a sufficient factor of common febrile reactions observed in early posttransplant neutropenia, thus supporting pathogenic significance of this infection, at least, in a subgroup of immunocompromised patiens. Development of these febrile responses could be either virus-induced, or combined with secondary bacterial infections caused by slow recovery of cellular immunity.

\section{Discussion}

The issue of optimal PVB19 diagnostics in heavily treated hematological patients is not yet clear, since the results of serological tests (serum IgM and IgG antibodies) did not correlate with detection of viral DNA in blood serum or bone marrow from the HSCT recipients [9]. In our study, a pilot group of the HSCT patients was studied for PVB19 DNA and specific serum antibodies before and at 30-60 days following transplantation. Generally, PVB19 was found at, generally, in about $30 \%$ of this group. Remarkably, these figures were at rather low levels, both pre-transplant and after HSCT and did not sufficiently increase post-translant. Mean initial concentrations of PVB19 DNA did not correlate either with age of the patients, or with clinical disease status, physical state, or activation of other latent viruses. IgM antibodies to PVB19 were not detectable in HSCT patients, thus suggesting absence of de novo infection. However, class IgG antibodies (>10 IU/ml) were, found in ca $70 \%$ of cases thus presuming previous contacts with the virus. Hence, the background levels of parvovirus exist both pre- and posttransplant.

A search for associations between PVB19 positivity and specific antibody production have shown a significant correlation between pre-transplant PVB19 load and expressed IgG antibody response detected 60 days after allo-HSCT, i.e., the non-zero viral loads were associated with higher contents of specific antibodies, thus suggesting an association between the PVB19 persistence and production of virus-specific antibodies.

\section{Conclusions}

1. Presence of parvovirus B19 in peripheral blood of children before allogeneic hematopoietic stem cell transplantation is followed by increased PV-specific antibodies of IgG class in blood serum at all terms after allo-HSCT.

2. Increased IgG levels of antibodies in blood of the patients after allo-HSCT is associated with relative neutropenia and thrombocytopenia at first 2 months after allo-HSCT.

3. Detection of parvovirus DNA at initial terms (before HSCT) and and 30-60 days later may be followed by development of early febrile neutropenias and slower recovery of erythrocyte and platelet counts in peripheral blood.

Table 4. Differences in PVB19 levels for the patients with vs without febrile neutropenia $(p=0.015)$

\begin{tabular}{|l|l|l|}
\hline & Febrile neutropenia & Free of febrile neutropenia \\
\hline Number of patients & 37 & 11 \\
\hline Mean copy number of PVB19 per ml plasma & 42.37 & 0 \\
\hline Standard deviation & 77.01 & 0 \\
\hline Standard error & 12.7 & 0 \\
\hline
\end{tabular}




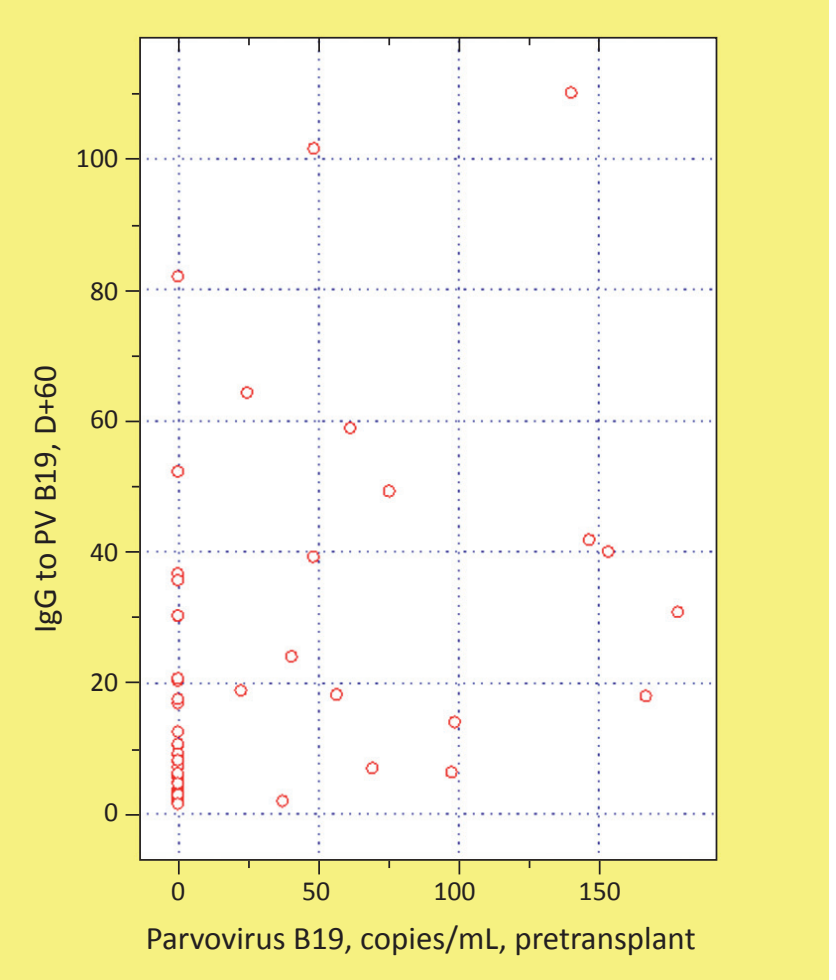

Figure 1. Association between initial PVB19 viral load (day 0), and IgG antibodies to PVB19 by day 60 ( $r=0.464$; $\mathrm{p}=0.0004$ ). Abscissa, parvovirus concentration (copies per $\mathrm{mL}$ ); ordinate, amounts of specific IgG antibodies, expressed as IU/ml, at 2 months after HSCT

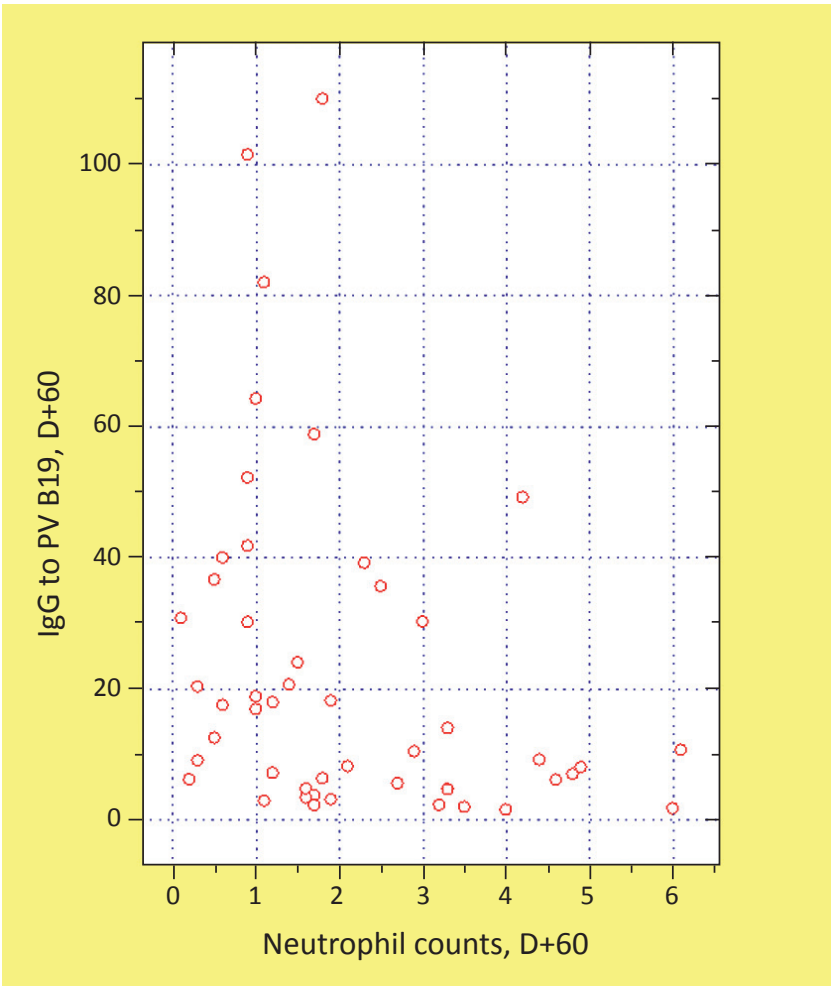

Figure 3. Negative correlation between the blood neutrophil counts, and amounts of PVB19-specific antibodies, expressed as $\mathrm{IU} / \mathrm{ml}$, at the day +60 post-HSCT $(r=-0.422 ; p=0.002)$

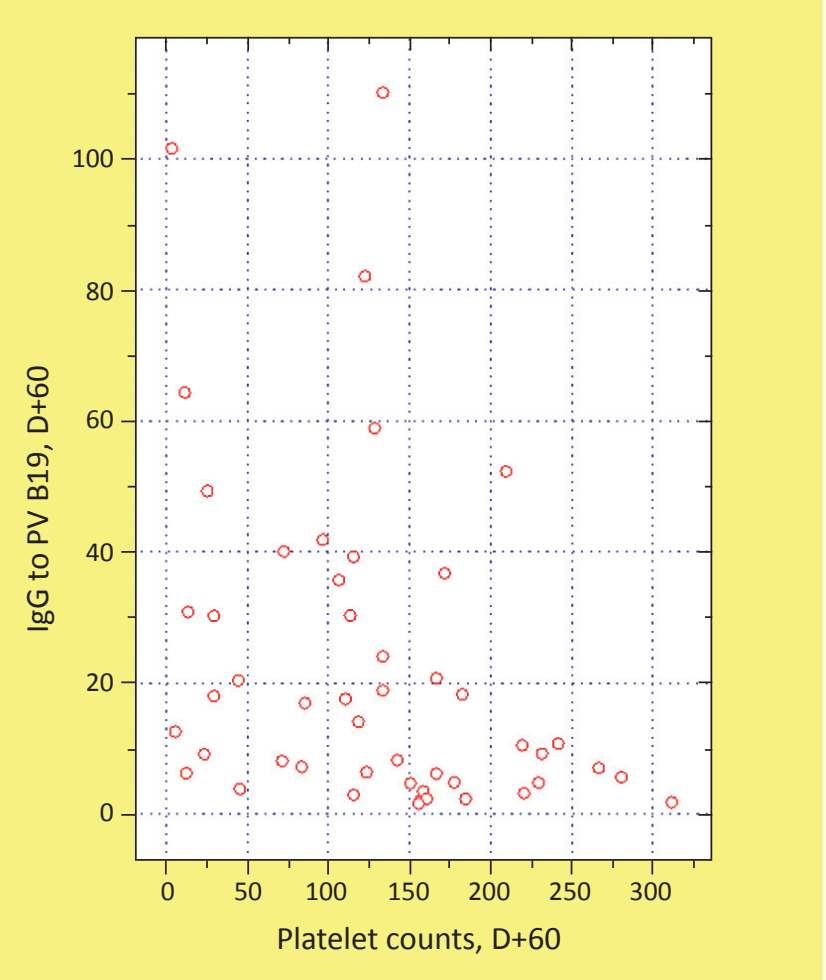

Figure 2. Negative correlation between blood platelet counts $\left(10^{9}\right.$ per $\left.\mathrm{mL}\right)$, and $\mathrm{IgG}$ anti-PV B19 antibodies, expressed as IU/ml, at the day +60 post-HSCT $(p=0.001$; $r=-0.422$ )

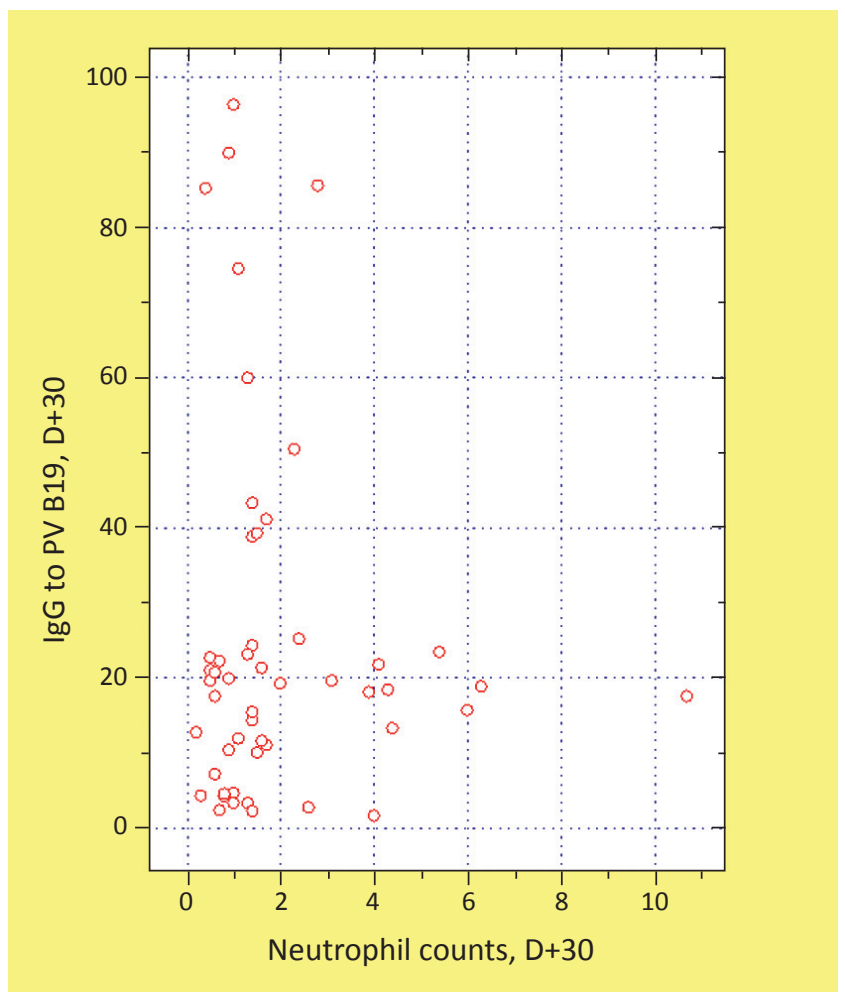

Figure 4. Negative correlation between blood neutrophil contents, and amounts of PVB19-specific antibodies, expressed as $\mathrm{IU} / \mathrm{ml}$, at the day +30 postalloHSCT $(r=-0.380 ; p=0.003)$ 


\section{Conflict of interest}

The authors report no conflicts of interest.

\section{References}

1. Asano Y, Yoshikawa T. Human herpesvirus-6 and parvovirus B19 infections in children. Curr Opin Pediatr. 1993;5(1):14-20.

2. Lee TH, Kleinman SH, Wen L, Montalvo L, Todd DS, Wright DJ, Tobler LH, Busch MP; NHLBI Retrovirus Epidemiology Donor Study-II (REDS-II). Distribution of parvovirus $\mathrm{B} 19$ DNA in blood compartments and persistence of virus in blood donors. Transfusion. 2011;51(9):1896-908.

3. Urban C, Lackner H, Müller E, Benesch M, Strenger V, Sovinz P, Schwinger W. Stem cell transplantation in 6 children with parvovirus B19- induced severe aplastic anaemia or myelodysplastic syndrome. Klin Pädiatr. 2011;223(6):332334.

4. Egbuna O, Zand MS, Arbini A, Menegus M, Taylor J. A cluster of parvovirus B19 infections in renal transplant recipients: a prospective case series and review of the literature. Am J Transplant. 2006;6(1):225-231.

5. Corcioli F, Zakrzewska K, Rinieri A, Fanci R, Innocenti M, Civinini R, De Giorgi V, Di Lollo S, Azzi A. Tissue persistence of parvovirus B19 genotypes in asymptomatic persons. J Med Virol. 2008;80(11):2005-2011.

6. Gama BE, Emmel VE, Oliveira-Silva M, Gutiyama LM, Arcuri L, Colares M, de Cássia Tavares R, Bouzas LF, Abdelhay E, Hassan R. Parvovirus B19 in the Context of Hematopoietic Stem Cell Transplantation: Evaluating Cell Donors and Recipients. Transplant Direct. 2017;3(11):e217. doi: 10.1097/TXD.0000000000000731.

7. Pankratova OS, Chukhlovin AB. Time course of immune recovery and viral rwactivation following hematopoietic stem cell transplantation. Cell.Ther Transplant. 2016; 5(4):32-43.

8. Rahiala J, Koskenvuo M, Norja P, Meriluoto M, Toppinen M, Lahtinen A, Väisänen E, Waris M, Vuorinen T, Saarinen-Pihkala U, Lappalainen M, Allander T, Ruuskanen O, Hedman K, Söderlund-Venermo M, Vettenranta K. Human parvoviruses B19, PARV4 and bocavirus in pediatric patients with allogeneic hematopoietic SCT. Bone Marrow Transplant. 2013;48(10):1308-1312.

9. Lundqvist A, Tolfvenstam T, Brytting M, Stolt CM, Hedman K, Broliden K. Prevalence of parvovirus B19 DNA in bone marrow of patients with haematological disorders. Scand J Infect Dis. 1999;31(2):119-122.

10. Kontermann RE. Strategies to extend plasma half-lives of recombinant antibodies. Biodrugs. 2009; 23(2): 93-109. 


\title{
Частота выявления парвовируса В19, специфического антительного ответа и задержка восстановления гемопоза после аллогенной трансплантации гемопоэтических стволовых клеток
}

\author{
Ирина В. Хамитова, Ирина Н. Лаврентьева, Мария Ю. Аверьянова, Алексей Б. Чухловин, \\ Людмила С. Зубаровская, Борис В.Афанасьев \\ НИИ эпидемиологии и микробиологии им. Пастера, Санкт-Петербург, Россия; НИИ детской онкологии, гематологии \\ и трансплантологии им. Р. Горбачевой, Первый Санкт-Петербургский государственный медицинский университет \\ им. И. П. Павлова, Санкт-Петербург, Россия
}

Д-р Ирина В. Хамитова, руков. центральной клиникодиагностической лаборатории НИИ эпидемиологии и микробиологии им. Пастера, ул. Мира д. 14, 197101, Санкт-Петербург, Россия
Телефон: +7 (812) 2323155

E-mail: irina.khamitova@gmail.com

\section{Резюме}

Парвовирус В19 (ПВ В19) является хорошо известным ДНК-вирусом, который, возможно, ассоциирован с нарушениями эритропоэза. Будучи латентным вирусом, ПВ В19 может активироваться у пациентов с ослабленным иммунитетом. Однако клиническое значение PV B19 после трансплантации гемопоэтических стволовых клеток (ТГСК) до сих пор не выяснено. Поэтому целью нашего исследования было сравнение уровней ПВ В19 до аллогенной ТГСК и через 1-2 месяца после трансплантации, а также поиск корреляций между наличием вируса и уровнями специфических антител, а также возможным влиянием вируса на восстановление гемопоэза в пределах 60 сут. после ТГСК. Наше исследование включало 54 больных детского и подросткового возраста (0.6-19 лет) с онкогематологическими заболеваниями или наследственной патологией, которым проводили аллогенную ТГСК. Из этой группы, 51 пациента наблюдали в течение, по крайней мере, 60 дней после ТГСК. 33\% больных этой группы находились в первой ремиссии после предыдущего лечения. Немиелоаблативное кондиционирование применяли в 94\% случаев. Антилимфоцитарный иммуноглобулин и/или циклофосфамид применяли в качестве иммуносупрессивной терапии. Определение ДНК ПВ В19, а также герпесвирусов (CMV, EBV, $\mathrm{HSV}$ ) и полиомавирусов (BK, JC) проводили до кондиционирующей терапии, предшествующей ТГСК, а также в дни +30 и +60 после трансплантации. Количественное определение ПВ В19 осуществляли с помощью геноспецифической ПЦР в реальном времени коммерческой тест-системой. Антитела классов IgG and IgM к ПВ В19 определяли в количественном формате методом ИФА.

Получены следующие результаты: невысокие уровни ДНК ПВ В19 были обнаружены в плазме крови у 31.5\% пациентов данного контингента. Однако $68 \%$ этих больных имели значимые уровни антител класса $\operatorname{IgG}$ к парвовирусу В19 в плазме крови (>10 MЕ/мл), что отражает высокую частоту адаптивного иммунного ответа на данный вирус. В целом, встречаемость и средние уровни ДНК ПВ B19, а также концентрации антител к парвовирусу В19 не проявляют существенных изменений в течение 30-60 суток после ТГСК.

Между тем, показана существенная положительная корреляция между вирусной нагрузкой ПВ В19 по всему массиву данных и уровнями специфических антител класса IgG $(\mathrm{r}=0.351 ; \mathrm{p}<0.0001)$. Кроме того, ПЦР-позитивность по ПВ В19 на день +30 после алло-ТГСК была во всех случаях (14/14) ассоциирована с диагностированной фебрильной нейтропенией у этих пациентов, что предполагает потенциальную роль парвовирусной инфекции в генезе посттрансплантационных инфекций.

В частности, важные корреляции показаны между исходным выявлением ДНК парвовируса и отложенным восстановлением числа эритроцитов и тромбоцитов в периферической крови (соответственно, $\mathrm{r}=-0,281 ; \mathrm{p}=0.02$, и $\mathrm{r}=-0,303, \mathrm{p}=0.01)$. Выявлена и достоверная корреляция между сниженными уровнями нейтрофилов и тромбоцитов через 60 сут., и повышенными титрами антител IgG к PV B19 в этот срок. Данные факты допускают ассоциацию между активацией парвовируса В19 и замедленным восстановлением гемопоэза после аллогенной ТГСК.

\section{Ключевые слова}

Трансплантация гемопоэтических стволовых клеток, парвовирус В19, активация, антивирусные антитела, миелосупрессия, фебрильная нейтропения. 